\title{
Faktor-Faktor yang Mempengaruhi Pengguna Napza Suntik dalam Tindakan Pemanfaatan Layanan Program Terapi Rumatan Methadon (PTRM) di Kota Cirebon
}

\author{
Dessy Aryanti*) Bagoes Widjanarko**) Kusyogo Cahyo**) \\ *) RSUD Gunung Jati Kota Cirebon \\ Email: dessyary2008@yahoo.com \\ **) Magister Promosi Kesehatan Universitas Diponegoro Semarang
}

\begin{abstract}
ABSTRAK
Faktor resiko penularan HIV/AIDS akibat penggunaan napza suntik adalah yang terbanyak setelah kelompok heteroseksual dan homo-biseksual. Program Terapi Rumatan Methadon (PTRM) termasuk dalam program Harm Reduction merupakan program pengurangan dampak buruk penggunaan napza suntik dalam pencegahan penularan HIV/AIDS. Penelitian ini merupakan penelitian kuantitatif dengan desain korelasional menggunakan metode angket kuesioner. Sampel penelitian adalah total populasi yaitu seluruh pengguna napza suntik (penasun) di wilayah Kota Cirebon yang berjumlah 50 penasun. Dari 50 penasun yang menjadi responden dalam penelitian ini diketahui bahwa $68 \%$ tidak memanfaaatkan layanan PTRM. Hal disebabkan sebagian besar penasun masih belum bisa berhenti menggunakan napza suntik dan belum mau beralih ke PTRM. Hasil analisis univariat diketahui tingkat pengetahuan penasun tentang PTRM 88\% memiliki kategori baik, sikap penasun 80\% mendukung PTRM, sikap keluarga 50\% mendukung PTRM, sikap teman sebaya 72\% mendukung PTRM, sikap petugas kesehatan 66\% mendukung PTRM, dan ketersediaan sarana dan fasilitas kesehatan 52\% mendukung layanan PTRM. Untuk hasil analisis bivariate menunjukkan bahwa pengetahuan tidak ada hubungan terhadap PTRM, sedangkan sikap penasun, sikap keluarga, sikap teman sebaya, sikap petugas kesehatan, dan ketersediaan sarana dan fasilitas kesehatan menunjukkan ada hubungan yang bermakna terhadap PTRM. Dan berdasarkan analisis multivariat diketahui bahwa sikap keluarga penasun yang paling dominan mempengaruhi tindakan penasun dalam pemanfaatan layanan PTRM.
\end{abstract}

Kata Kunci : Napza, suntik, PTRM, HIV/AIDS

\section{ABSTRACT}

According to the risk factors as a result of injecting drug use (IDU) were second highest, after the heterosexual and homo-bisexual. In IDUs face two risks for contracting HIV / AIDS, from the use of unsterilized needles and performed together or alternately with other IDUs and also through sexual intercourse, especially that done with more than one partner without using a condom. Methadone maintenance treatment program (PTRM) is included in the Harm Reduction program - This is a program of harm reduction drug use in preventing transmission of HIV / AIDS. This research is quantitative with correlational design, sampling using the technique across sectional the total population 50 person IDUs of injecting drug users in the city of Cirebon -use structured questionnaires technique. From the 50 IDUs who were respondents in this research note that $68 \%$ did not use PTRM services. It is because most IDUs still can not stop using injection drugs and have not been willing to switch to PTRM. Results of univariate analysis to determine the level of knowledge of IDUs about PTRM $88 \%$ have a good category, the attitude of the respondents $80 \%$ have category support PTRM, family attitudes 50\% have category support PTRM, attitudes of peers $72 \%$ have a category does not support the utilizations PTRM, attitude of health workers $66 \%$ category does not support PTRM, and the availability of facilities and health facilities 52\% support in PTRM services. For the bivariate analysis showed that the attitude of IDUs to program substitution therapy methadone-related measures the utilization of PTRM, whereas 
knowledge factors, family attitudes, attitudes of peers, attitude of health workers, and the availability of facilities. Then knowledge of IDUs about PTRM shows no relationship with the actions the utilization of PTRM, And based on multivariate analysis known that the action the utilization of PTRM is influenced by the family attitudes were supportive of the utilizations of Methadone maintenance treatment program (PTRM).

Keywords: drug, injection, PTRM, HIV/AIDS

\section{PENDAHULUAN}

Indonesia saat ini sedang dihadapkan dengan masalah peredaran narkoba dan sanksi hukum yang dijatuhkan bagi para eksportir, importir, produsen, bandar, dan pengedar narkoba. Melihat kondisi ini, pemerintah Indonesia lebih tegas dalam upaya pemberantasan peredaran narkoba yang sudah menyentuh seluruh lapisan masyarakat. Menurut data dari $\mathrm{BNN}$, jumlah pengguna narkoba di Indonesia hingga saat ini sekitar 5,1 juta orang dari 250 juta penduduk Indonesia. Jumlah ini akan terus bertambah apabila tidak ada upaya yang serius dari pemerintah untuk pemberantasan peredaran narkoba di Indonesia (BNN RI, 2015).

Beberapa faktor resiko penyebab penularan HIV, yaitu : hubungan seks beresiko pada heteroseksual, hubungan seks beresiko pada homo-biseksual, pengguna napza suntik, transfusi darah, dan transmisi perinatal. Penyalahgunaan narkoba dibeberapa negara termasuk Indonesia menjadi faktor kedua dalam penyebaran HIV (Human Immunodeficiency Virus). Selain efek dari narkoba dan penggunaan alat suntik yang bergantian dengan pengguna narkoba yang lain menyebabkan penularan penyakit infeksi dan HIV/AIDS di kalangan pengguna narkoba suntik (Irianto, 2014).

Dalam triwulan Juli s.d. September 2014 dilaporkan tambahan HIV sebanyak 7.335 kasus dan AIDS sebanyak 176 kasus. Jumlah HIV \& AIDS yang dilaporkan 1 Januari s.d. 30 September 2014 yaitu 22.869 kasus HIV dan 1.876 kasus AIDS. Secara kumulatif dari 1 April 1987 s.d. 30 September 2014 jumlah HIV 150.296 kasus dan AIDS 55.799 kasus dengan jumlah kematian sebanyak 9.796 orang. Kasus terbanyak pada laki-laki 30.001 kasus. Menurut faktor resiko akibat heteroseksual 34.305 kasus, homobiseksual 1.366 kasus, penasun 8.462 kasus, transfusi darah 130 kasus, transmisi perinatal 1.506 kasus, dan yang tak diketahui 9.536 kasus. Sedangkan menurut kelompok umur tertinggi pada umur 20 29 tahun sebanyak 18.532 kasus dan umur 30 - 39 tahun sebanyak 15.890 kasus, untuk yang terendah pada umur $<1$ tahun sebanyak 238 kasus (DITJEN PP dan PL KEMENKES RI, 2014).

Di wilayah Cirebon pada tahun 2013, jumlah kasus HIV-AIDS meningkat 
75 \%. Hingga akhir November 2013 tercatat 75 kasus dan mayoritas kasus menimpa warga berusia produktif, antara usia 25-29 tahun. Jumlah ini meningkat dibanding tahun 2012. Saat ini sedikitnya 56 orang yang tercatat tewas akibat AIDS dalam kurun waktu 4 tahun ini dari jumlah total warga yang terinfeksi HIV-AIDS, yakni sebanyak 628 orang. Angka kasus penularan HIV/AIDS di Kota Cirebon mengalami peningkatan cukup signifikan bahkan berdasarkan data kasus yang ada dan dibandingkan jumlah penduduk, angkanya paling tinggi di Jawa Barat. Pada tahun 2014 mencapai 700 kasus di Kota Cirebon jika dibandingkan dengan jumlah penduduk sekitar 380.000 jiwa, persentasenya paling tinggi jika dibandingkan dengan Bandung atau daerah lain di Jawa Barat. Keberadaan pelabuhan di Kota Cirebon merupakan hal yang perlu diantisipasi karena bukan hanya menjadi pintu masuk barang akan tetapi jadi gerbang masuk potensi berbagai masalah seperti penyakit berbahaya dan Narkoba. Tingginya penyebaran HIV/AIDS di Kota Cirebon masih didominasi dari penggunaan narkoba jenis suntik dan perilaku seks bebas (KPA Kota Cirebon, 2013).

Dari 12 program Harm Reduction di tiga Puskesmas yang ditunjuk terutama untuk layanan distribusi jarum suntik steril, layanan penukaran jarum suntik bekas pakai, dan layanan konseling dan test HIV sukarela (Volluntary Counselling and Testing HIV) kurang berjalan secara maksimal. Untuk layanan distribusi jarum suntik steril dan layanan penukaran jarum suntik bekas pakai tidak berjalan dengan baik karena jenis alat suntik yang kurang disukai oleh para penasun dengan alasan kualitas jarum suntik yang kurang baik, dikenakan biaya Rp.15.000,-/paket, dan penasun jarang datang ke puskesmas untuk menukarkan jarum suntik bekas pakainya. Oleh karena itu para penasun lebih sering membeli langsung ke apotik atau ke tokotoko alat kesehatan, tetapi bila tidak memungkinkan untuk membeli, maka penyuntikan dilakukan secara bergantian dengan penasun lain. Ada juga penasun yang mencuci alat suntiknya dengan air biasa atau larutan penyuci hama, namun tindakan yang dilakukan tidak sesuai dengan prosedur tindakan yang benar (Tim PTRM RSUD Gunung Jati, 2014).

Program Harm Reduction dalam pengurangan dampak buruk napza selain mencakup 12 program Harm Reduction, untuk layanan terapi Methadon di klinik PTRM RSUD Gunung Jati Kota Cirebon, meliputi : layanan pemberian terapi Methadon, layanan konseling pada pasien dan keluarga, layanan konseling adiksi pada pasien, dan pertemuan rutin dengan pasien setiap bulan. Saat ini program yang berjalan hanya layanan pemberian terapi 
Methadon saja, untuk program layanan yang lain kurang berjalan dengan baik dikarenakan keterbatasan jumlah petugas layanan yang terlatih, serta pasien dan keluarga kurang memanfaatkan program layanan konseling yang ada. Menurut petugas klinik PTRM, program evaluasi terapi methadon pada pasien melalui test urine tidak dapat dilakukan secara intensif, karena test urine dilakukan atas kesediaan pasien untuk melakukan test berdasarkan anjuran petugas PTRM dengan biaya yang dibebankan ke pasien. Test urine dilakukan bertujuan untuk mengevaluasi kepatuhan penasun dalam menjalankan terapi methadon atau untuk mengetahui apakah penasun selama menjalankan terapi methadon juga masih menggunakan napza suntik. Maka rumusan masalah penelitian ini adalah tentang faktor-faktor yang mempengaruhi pengguna napza suntik (penasun) dalam pemanfaatan layanan Program Terapi Rumatan Methadon (PTRM) di Kota Cirebon. Tujuanya untuk mengetahui apakah ada hubungan dan pengaruh antara faktor pengetahuan penasun tentang PTRM, sikap penasun terhadap PTRM, sikap keluarga terhadap PTRM, sikap teman sebaya terhadap PTRM, sikap petugas kesehatan terhadap PTRM, dan ketersediaan sarana dan fasilitas kesehatan dengan tindakan penasun dalam pemanfaatan layanan PTRM.

\section{METODE}

Jenis penelitian yang digunakan adalah penelitian kuantitatif dengan desain penelitian korelasional. Desain korelasional bertujuan untuk mendapatkan gambaran tentang hubungan atau pengaruh antara dua atau lebih variabel-variabel penelitian (Santoso, 2015). Tehnik pengambilan sampel pada penelitian ini dengan menggunakan tehnik Total Population yaitu seluruh jumlah populasi yang ada diambil sebagai sampel penelitian yang berjumlah 50 orang. Pengumpulan data dilakukan dengan tehnik angket menggunakan kuesioner terstruktur yang berisi pernyataan atau pertanyaan tertutup dengan pilihan jawaban yang tersedia.

\section{HASIL DAN PEMBAHASAN}

\section{Karakteristik Responden}

Diketahui bahwa seluruh responden yaitu 50 penasun (100\%) yang ada di wilayah Kota Cirebon sebagian besar adalah laki-laki, $66 \%$ berumur antara 31 40 tahun, $86 \%$ berpendidikan SLTA, $48 \%$ menikah, 44\% adalah karyawan swasta, dan lamanya menggunakan napza 98\% > 2 tahun.

Untuk tindakan pemanfaatan layanan PTRM diketahui bahwa dari 50 responden terdapat 34 responden (68\%) yang tidak memanfaatkan layanan PTRM. Sebagian besar menyatakan belum bisa 
meninggalkan napza suntik. Berdasarkan karakteristik responden yang sebagian besar berusia 31 - 40 tahun, berpendidikan SLTA dan perguruan tinggi, serta menikah tidak dapat dijadikan sebagai tolak ukur bagi seseorang untuk mengambil keputusan yang positif, dalam hal ini yaitu keputusan untuk beralih dari perilaku beresiko penggunaan napza suntik ke terapi methadon. Karena diharapkan dengan usia yang sudah matang dan didukung dengan tingkat pendidikan yang tinggi, para penasun dapat berpikir secara dewasa sehubungan dengan peran dan beban tanggung jawab mereka terhadap keluarga dan masyarakat serta faktor resiko yang mereka hadapi akibat dari perilaku penggunaan napza suntik terhadap penularan HIV/AIDS.

Sebagian besar responden bekerja sebagai karyawan swasta dan wiraswasta dengan latar pendidikan SLTA dan Perguruan tinggi yang mereka miliki dan sebagian besar merahasiakan status pengguna napza dan status HIV positifnya. Sebagian responden tidak bekerja atau bekerja tidak tetap misalnya sebagai tukang parkir atau tenaga buruh.

Pemberian informasi sangat penting melalui program Komunikasi, Informasi, dan Edukasi (KIE) tentang peningkatan dan pemeliharaan kesehatan dengan cara mempertahankan perilaku hidup sehat bagi penasun dan penderita HIV positif untuk peningkatan dan mempertahankan kualitas hidup penasun dan penderita HIV positif agar tetap produktif baik bagi dirinya dan keluarganya.

Program KIE merupakan kegiatan yang dikembangkan secara khusus dalam penyediaan informasi mengenai HIV/AIDS, napza, risiko penularan HIV (dari berbagi jarum suntik dan hubungan seks), seksualitas, merawat diri dengan lebih baik, dan isu lain yang berhubungan dengan permasalahan kesehatan penasun.

Program ini bertujuan untuk meningkatkan pengetahuan dan sikap yang dapat mendorong ke arah perubahan perilaku dalam mengurangi resiko terinfeksi HIV, serta menyediakan dan memberikan informasi yang benar dan tepat guna. Yang menjadi sasaran utama (primer) adalah penasun, pengguna napza, dan pasangan seks penasun, sasaran kedua (sekunder) adalah keluarga penasun, dan sasaran ketiga (tersier) adalah masyarakat luas.

\section{Pengetahuan Responden tentang PTRM}

Pengetahuan responden adalah kemampuan responden untuk mengetahui dan memahami tentang layanan PTRM. Dan sebagian besar pengetahuan manusia diperoleh dari indra penglihatan dan pendengaran. Pengetahuan merupakan dolain kognitif yang sangat penting dalam membentuk perilaku atau tindakan 
seseorang. Pengukuran pengetahuan dapat dilakukan dengan wawancara atau angket yang menanyakan tentang isi materi yang ingin diukur dari subjek penelitian atau responden (Notoatmadjo, 2010).

Dari hasil penelitian diketahui bahwa sebagian besar responden $(88 \%)$ memiliki pengetahuan yang baik tentang PTRM. Berdasarkan hasil dari uji statistic diperoleh nilai $p$ value $=0.159$ ( $p$ value $>$ 0.05) maka dapat disimpulkan bahwa tidak terdapat hubungan yang bermakna antara Pengetahuan dengan tindakan pemanfaatan layanan PTRM.

Hal ini kemungkinan disebabkan karena tingkat pendidikan responden yang sebagian besar tamat SLTA 43 orang $(86 \%)$ dan 7 orang (14\%) tamat Akademi/Perguruan Tinggi. Selain dari tingkat pendidikan responden yang sebagian besar SLTA dan Akademi/Perguruan Tinggi, kemungkinan tingginya pengetahuan responden disebabkan karena penjangkauan dan pendampingan yang dilakukan oleh petugas outreach dan dibantu teman sebaya yaitu tenaga sukarela dari mantan pengguna napza yang memberi peluang bagi penasun untuk dapat mengakses berbagai informasi dan layanan kesehatan yang dibutuhkan terutama layanan PTRM.

Hasil penelitian ini juga sesuai dengan hasil penelitian Astuti yang menyatakan bahwa tidak ada hubungan antara pengetahuan tentang terapi methadon dengan kejadian drop out pasien PTRM. Dari data diketahui bahwa sebagian besar pengetahuan responden pada kategori sedang. Pengetahuan seseorang mengandung aspek positif dan aspek negatif. Semakin banyak aspek positif terhadap suatu objek, maka akan menimbulkan sikap atau perilaku yang positif, begitu pula dengan aspek negatif akan menimbulkan sikap atau perilaku yang negatif (Astuti, 2015).

Sedangkan menurut teori Bloom tentang tingkatan pengetahuan, yang terdiri dari : tahu, memahami, aplikasi, analisis, sintesis, dan evaluasi. Dari tingkatan ini diketahui bahwa tahu merupakan tingkat pengetahuan yang paling rendah. Seseorang yang mempunyai tingkat pengetahuan yang tinggi dilihat dari kemampuannya dalam memahami dan mengaplikasikannya dalam bentuk tindakan yang positif serta mampu melakukan evaluasi dan penilaian berdasarkan pengetahuan yang dimiliki. Apabila seseorang bertindak atau berperilaku tidak sesuai dengan pengetahuan yang dimiliki, maka seseorang tersebut dapat dikatakan hanya sekedar tahu tapi tidak atau belum memahami tentang suatu materi atau objek (Notoatmodjo, 2012). 
Sikap Penasun terhadap PTRM

Sikap merupakan reaksi atau respons yang masih tertutup dari seseorang terhadap suatu stimulus atau objek. Sikap secara nyata menunjukan konotasi adanya kesesuaian reaksi terhadap stimulus tertentu yang dalam kehidupan sehari-hari merupakan reaksi yang bersifat emosional terhadap stimulus sosial. sikap merupakan kesiapan atau kesediaan untuk bertindak dan bukan merupakan pelaksanaan motif tertentu. Sikap belum merupakan suatu tuindakan akan tetapi merupakan predisposisi tindakan suatu perilaku. Sikap merupakan reaksi tertutup, bukan merupakan reaksi atau tingkah laku yang terbuka (Notoatmodjo, 2012).

Pengukuran sikap ini dapat dilakukan secara langsung dan tidak langsung. Secara langsung dapat ditanyakan bagaimana pendapat atau pernyataan responden terhadap suatu objek. Sikap dapat bersifat positif dan dapat pula bersifat negatif. Sikap positif adalah kecenderungan tindakan untuk mendekati, menyenangi, dan mengharapkan objek tertentu. Sedangkan sikap negatif adalah kecenderungan tindakan untuk menjauhi, menghindari, membenci, dan tidak menyukai objek tertentu (Wawan dan Dewi, 2011).

Dari data didapat bahwa $58 \%$ responden memiliki sikap mendukung terhadap PTRM dan $68 \%$ responden tidak memanfaatkan atau menggunakan layanan PTRM. Berdasarkan hasil uji statistic diperoleh nilai $P$ value $=0.020 \quad(<0.05)$ maka dapat disimpulkan bahwa terdapat hubungan yang bermakna antara Sikap Penasun dengan tindakan pemanfaatan layanan PTRM.

Dari hasil penelitian diketahui bahwa sebagian besar responden masih mempunyai sikap yang negatif terhadap program terapi methadon dengan sikap mendukung terhadap PTRM tetapi belum atau tidak memanfaatkan layanan PTRM yang ada.

Begitu juga dari hasil penelitian yang dilakukan Isfandari yang menyatakan bahwa faktor yang paling mempengaruhi penasun dalam terapi rumatan methadon adalah sikap penasun yang mendukung terhadap program terapi methadon. Dikatakan bahwa sikap dapat diposisikan sebagai hasil evaluasi terhadap objek sikap yang diekspresikan ke dalam proses kognitif, afektif, dan konatif (Isfandari, 2009).

Hasil penelitian ini juga sesuai dengan hasil penelitian Anggraini yang menunjukkan adanya kesenjangan antara kelompok penasun yang mendukung dengan kelompok penasun yang mayoritas (66\%) tidak mendukung atau menyatakan ketidaksetujuan terhadap PTRM. Dari hasil penelitiannya bahwa penasun masih memiliki sikap negatif terhadap PTRM 
karena penasun merasa malu untuk datang ke klinik PTRM. Penasun merasa rendah diri dan mendapat pandangan negatif (stigma) dari masyarakat. Penasun tidak yakin dengan keberhasilan PTRM dan manfaat yang mereka dapatkan setelah menjalankan PTRM (Anggraini, 2012).

Hasil penelitian ini juga sesuai dengan teori perilaku dimana sikap merupakan respon atau reaksi yang masih tertutup dari seseorang terhadap suatu stimulus atau objek. Sikap merupakan kesiapan seseorang untuk bertindak dan merupakan predisposisi suatu perilaku. Pengetahuan, keyakinan, dan emosi seseorang menjadi peran penting dalam menentukan sikap (Wawan dan Dewi, 2011).

Dengan pengetahuan dan pemahaman yang baik serta di dukung dengan sikap yang positif maka penasun juga akan bertindak positif dalam hal ini akan menggunakan atau memanfaatkan layanan PTRM yang ada.

\section{Sikap Keluarga terhadap PTRM}

Sikap keluarga adalah kecenderungan atau respon keluarga pada penasun terhadap tindakan pemanfaatan layanan PTRM. Sikap atau dukungan keluarga menjadi faktor pendukung penasun dalam menentukan sikap dan tindakannya terhadap PTRM dan memberikan dukungan pada penasun baik secara moril dan materil untuk memanfaatkan layanan PTRM dan menjalankan terapi methadon.

Dari hasil penilitian diketahui bahwa sebagian responden yaitu 25 responden $(50 \%)$ memiliki sikap keluarga yang mendukung responden dalam menjalankan terapi methadon. Berdasarkan hasil uji statistic diperoleh nilai $p$ value $=0.001$ (>0.05) maka dapat disimpulkan bahwa terdapat hubungan yang bermakna antara Sikap keluarga dengan pemanfaatan layanan PTRM.

Hasil penelitian ini sesuai dengan hasil penelitian Tampubolon yang menyatakan bahwa dukungan keluarga berhubungan dengan kepatuhan berobat ke Klinik PTRM Puskesmas Tanjung Marowa Kabupaten Deli Serdang. Keluarga dapat menjadi faktor yang sangat berpengaruh dalam menentukan keyakinan dan nilai kesehatan individu serta dapat juga menentukan program pengobatan yang akan dijalani (Tampubolon, 2011).

Kesesuaian ini dapat dijelaskan menurut teori perilaku bahwa sikap individu dipengaruhi oleh lingkungan, baik lingkungan internal maupun lingkungan eksternal. Lingkungan sosial terdekat seseorang atau individu adalah keluarga. Sehingga dukungan keluarga sangat besar pengaruhnya bagi individu dalam menentukan sikap atau membentuk pribadi 
seseorang dalam bertindak (Wawan dan Dewi, 2011).

\section{Sikap Teman Sebaya terhadap PTRM}

Sikap teman sebaya adalah kecenderungan atau respon teman sebaya pada penasun terhadap tindakan pemanfaatan layanan PTRM. Program pendidikan sebaya mempunyai kaitan yang erat dengan program penjangkauan dan pendampingan bagi para pengguna napza khususnya penasun dalam mendukung upaya untuk berbagi informasi didalam jaringan penasun, menyediakan dan memberikan informasi kepada penasun sehingga informasi tersebut dapat disebarkan oleh penasun kepada temantemannya yang lain, dan melibatkan para penasun dalam program intervensi sehingga mempunyai pengetahuan didalam pencegahan penularan HIV/AIDS agar dapat diinformasikan kepada penasun yang lain.

Dari data didapat bahwa sebagian besar teman sebaya responden ada 36 (72\%) yang menyatakan mendukung layanan PTRM. Berdasarkan hasil dari uji statistic diperoleh nilai $p$ value $=0.002$ ( $p$ value < 0.05$)$ maka dapat disimpulkan bahwa terdapat hubungan yang bermakna antara Sikap teman sebaya dengan pemanfaatan layanan PTRM.

Hasil penelitian hampir sama dengan hasil penelitian Winarno tentang norma teman sebaya yang tidak mendukung terhadap layanan jarum suntik steril. Dari data yang ada diketahui bahwa sebagian besar penasun mempunyai anggapan bahwa teman sebaya mendukung penggunaan jarum suntik bergantian, dan tidak seorangpun yang selalu menggunakan jarum suntik baru, serta tidak satupun dari teman sebaya yang memotivasi penasun untuk menggunakan jarum suntik baru saat menyuntik (Winarno, 2008).

\section{Sikap Petugas Kesehatan terhadap PTRM}

Sikap petugas kesehatan adalah kecenderungan atau respon petugas kesehatan terhadap layanan PTRM. Dalam layanan PTRM ada beberapa kegiatan yang dilakukan oleh petugas kesehatan, antara lain : penjangkauan dan pendampingan pada pengguna napza suntik, penyuluhan yang meliputi program komunikasi, informasi, dan edukasi yaitu merupakan kegiatan dalam penyediaan informasi tentang HIV/AIDS, napza, resiko penularan HIVAIDS, dan seksualitas.

Berdasarkan analisis data diketahui bahwa $66 \%$ pernyataan responden tentang sikap petugas kesehatan masuk dalam kategori mendukung terhadap layanan PTRM. 
Berdasarkan hasil dari uji statistic diperoleh nilai $p$ value $=0.004(<0.05)$ maka dapat disimpulkan bahwa terdapat hubungan antara sikap petugas kesehatan dengan tindakan pemanfaatan layanan PTRM.

Menurut teori L. Green bahwa sikap dan perilaku petugas kesehatan merupakan faktor pendorong (reinforcing factors) yang dapat mendukung dan memperkuat terbentuknya perilaku individu, kelompok, dan masyarakat (Green, 2000).

\section{Ketersediaan Sarana dan Fasilitas}

\section{Kesehatan}

Ketersediaan sarana dan fasilitas kesehatan merupakan penilaian atau tanggapan penasun tentang ketersediaan sarana dan fasilitas layanan PTRM. Dengan tersedianya sarana dan fasilitas kesehatan di layanan PTRM dan mudah untuk dijangkau oleh masyarakat khususnya pengguna napza suntik menjadi faktor pendukung yang memungkinkan terwujudnya perilaku yang positif dari penasun dalam tindakan pemanfaatan layanan PTRM.

Hasil penelitian didapat bahwa $52 \%$ responden menyatakan bahwa ketersedian sarana dan fasilitas kesehatan mendukung terhadap layanan PTRM. Berdasarkan hasil dari uji statistik diperoleh nilai $p$ value $=0.006$ menunjukkan bahwa ada hubungan yang bermakna antara ketersediaan sarana dan fasilitas kesehatan dengan tindakan pemanfaatan layanan PTRM.

Menurut teori L. Green faktorfaktor yang mempengaruhi perilaku individu maupun kelompok antara lain adalah faktor pemungkin (enabling factors) yang memungkinkan suatu motivasi dapat diwujudkan dalam bentuk tindakan. Faktor pemungkin dapat berupa lingkungan yang dapat memfasilitasi pelaksanaan dari suatu tindakan baik oleh individu maupun kelompok, termasuk didalamnya adalah ketersediaan sarana, keterjangkauan sarana, kemampuan pelayanan, dan sumber daya masyarakat (Green, 2000).

\section{Tindakan Pemanfaatan Layanan PTRM}

Tindakan pemanfaatan layanan PTRM adalah respon penasun dalam pemanfaatan layanan PTRM dalam bentuk tindakan atau perilaku dalam pemanfaatan layanan PTRM.

Berdasarkan hasil penelitian diketahui bahwa sebagian besar responden belum menggunakan atau memanfaatkan layanan PTRM. Dari 50 responden terdapat $68 \%$ responden yang tidak memanfaatkan layanan PTRM. Sebagian besar menyatakan belum bisa meninggalkan napza suntik, walaupun 
sebagian besar responden menyatakan akan beralih ke terapi methadon.

Dan dari hasil analisa secara keseluruhan diketahui bahwa yang memiliki hubungan yang signifikan terhadap tindakan pemanfaatan layanan PTRM adalah variabel Sikap Penasun, Sikap Keluarga, Sikap Teman Sebaya, Sikap Petugas Kesehatan, dan Ketersediaan Sarana dan Fasilitas Kesehatan terhadap program terapi rumatan methadon (PTRM), karena memiliki nilai $\mathrm{p}<0,05$ dan Sig. $<0,25$.

Menurut teori L. Green bahwa jika seseorang mempunyai pengetahuan yang baik dan keyakinan yang kuat (predisposing factors) mungkin cukup untuk memulai suatu perilaku, tetapi hal itu tidak akan mencukupi bila orang tersebut tidak mampu mengakses sarana atau fasilitas yang diperlukan untuk melaksanakan perilaku tersebut. Begitu pula dengan faktor penguat (reinforcing factor) diantaranya adalah keluarga dan petugas kesehatan sebagai faktor pendukung bagi individu atau kelompok yang memberikan penghargaan dan dukungan sosial terhadap perilaku atau tindakannya. Faktor penguat juga dapat menjadi sesuatu yang merugikan atau sebagai hukuman yang akan menghentikan perilaku positif individu atau kelompok tersebut. Dan faktor pemungkin (enabling factors) berupa kondisi lingkungan yang memfasilitasi dari pelaksanaan suatu tindakan baik individu maupun kelompok termasuk didalamnya adalah ketersediaan, keterjangkauan, kemampuan pelayanan, dan sumber daya masyarakat merupakan anteseden dari perilaku yang memungkinkan suatu motivasi dapat terealisasikan (Green, 2000).

Hasil penelitian ini juga sesuai dengan penelitian yang dilakukan oleh Oktavianus yang menyatakan bahwa perilaku pengguna napza suntik terhadap tindakan program terapi rumatan methadon dipengaruhi oleh sikap penasun. Melalui sikap, kita memahami proses kesadaran yang menentukan tindakan nyata dan tindakan yang akan atau yang mungkin dilakukan oleh individu atau kelompok dalam kehidupan sosialnya (Oktavianus, 2010).

Begitu pula dengan hasil penelitian Pratiwi bahwa ada pengaruh positif antara dukungan keluarga dengan kepatuhan menjalankan terapi methadon. Keluarga pasien PTRM sebagian besar mendukung pasien untuk menjalankan terapi methadon. Tetapi diketahui dilapangan sering terjadi kehilangan kontrol dari keluarga terhadap pasien. Dan beberapa pasien menyatakan tidak ingin melibatkan keluarga dalam proses terapi (Pratiwi, 2012).

Sehingga dapat dikatakan bahwa proses kognitif, afektif, dan konatif 
merupakan anteseden dari sikap. Proses kognitif dapat terjadi dari informasi dan pengalaman secara langsung yang diperoleh individu atau kelompok yang berkaitan dengan pengetahuan, pandangan, dan keyakinan terhadap suatu objek. Dan proses afektif merupakan perasaan yang menyangkut aspek emosional. Aspek emosional inilah yang paling mendasari individu atau kelompok untuk bertahan atau bahkan dapat mengubah sikapnya terhadap suatu objek. Sedangkan proses konatif merupakan aspek kecenderungan berperilaku atau bertindak baik mengarah ke sikap positif atau sikap negatif terhadap sesuatu. Maka apabila penasun di dukung dengan aspek kognitif, afektif, dan konatif yang baik terhadap PTRM, maka penasun akan cenderung berperilaku atau bertindak positif dalam pemanfaatan layanan PTRM.

\section{SIMPULAN}

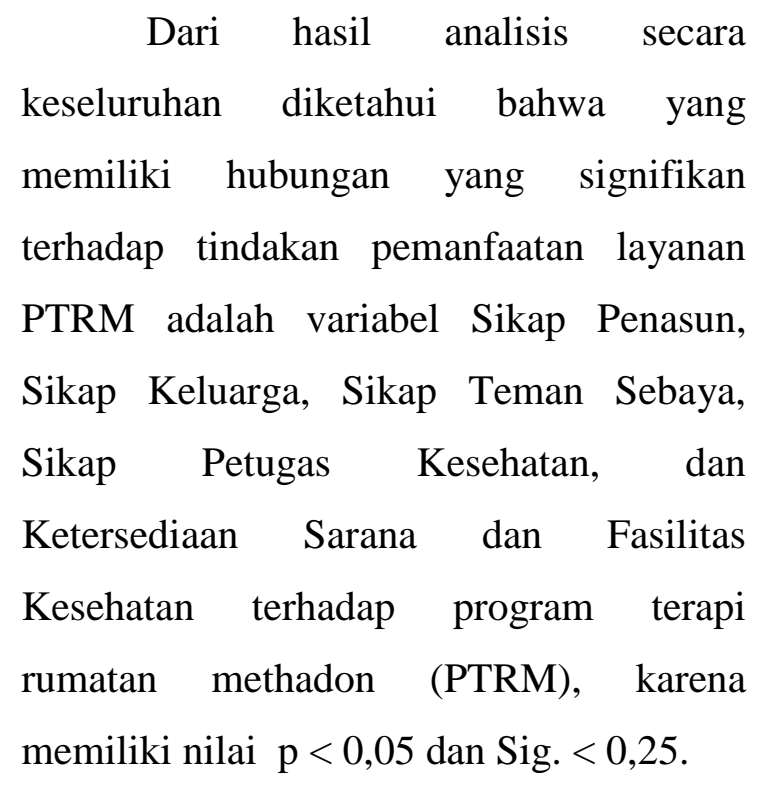

Terdapat pengaruh variabel yang paling dominan dalam tindakan pemanfaatan layanan PTRM yaitu Sikap Keluarga Penasun $(O R=10,941$ dan nilai Sig.=0,007) dan Sikap Petugas Kesehatan $(O R=5,938$ dan nilai Sig. $=0,20)$.

\section{KEPUSTAKAAN}

Anggraini, D.S. Perencanaan Social Marketing sebagai Upaya Peningkatan Pemanfaatan Terapi Rumatan Metadon. Dinas Kesehatan Propinsi Jawa Timur. Surabaya. 2012. Dari URL:http//www.akk64656fc6f2full .pdf. Diakses pada tanggal 28 Desember 2015.

Astuti R.I, Lenggono A.K, dan Hastuti P.A. Hubungan Pengetahuan tentang Terapi Methadon dengan kejadian Drop Out Pasien PTRM di Puskesmas Kendal Sri Kota Malang. $2015 . \quad$ Dari URL:http//www.ejournal.poltekes.a c.id. Diakses pada tanggal 20 Desember 2015.

Badan Narkotika Nasional Republik Indonesia. Analisa Data Pencegahan dan Pemberantasan Penyalahgunaan dan Peredaran Gelap Narkoba. BNN RI. Jakarta. 2015 
DITJEN PP dan PL KEMENKES RI. Statistik Kasus AIDS di Indonesia. . DEPKES RI. Jakarta. 2014

Green, W.L,Health Promotion Planning an Educational and Environmental Approach,. Mayfield Publishing company. London. 2000

Irianto.K. Epidemiologi Penyakit Menular dan Tidak Menular. Alfabeta. Bandung. 2014

Irianto, K. Bakteriologi Medis, Mikologi Medis, dan Virologi Medis. Alfabeta. Bandung. 2014

Isfandari S, Hanafi, dan Asril A. Tanggapan Pasien, Sikap Petugas, dan Penerimaan Masyarakat terhadap Program Terapi Rumatan Methadon. Badan Penelitian dan Pengembangan Kesehatan Depkes RI. $2009 . \quad$ Dari URL:http//www.ejournal.litbang.de pkes.go.id. Diakses pada tanggal 20 Desember 2015.

Komisi Penanggulangan AIDS Kota Cirebon. Laporan Kasus HIV/AIDS di Kota Cirebon. KPA Kota Cirebon. 2013

Notoadmodjo.S. Pendidikan dan Perilaku Kesehatan. Rineka Cipta. Jakarta. 2010

Notoadmodjo.S, Promosi Kesehatan dan Perilaku Kesehatan. Rineka Cipta. Jakarta. 2012
Oktavianus, P.P. Perilaku Pengguna Napza Suntik terhadap Tindakan Program Terapi Rumatan Methadon. USU. 2010. Dari URL:http//www.repository.usu.ac.i d. Diakses pada tanggal 20 Desember 2015.

Pratiwi Y.E. Dukungan Keluarga terhadap Kepatuhan Menjalankan Program Terapi pada Pasien Terapi Rumatan Methadon. Univeritas Negeri Semarang. 2012. Dari URL:http//www.ejournal.unnes.ac.i a/sju/index.php/dcp. Diakses pada tanggal 28 Desember 2015.

Santoso, S. Menguasai Statistik Multivariat. PT. Elex Media Komputindo Jakarta. 2015

Tampubolon, R.D. Hubungan Pengetahuan, Sikap, dan Dukungan Keluarga Pengguna Narkoba Suntik dengan Kepatuhan berobat ke Klinik PTRM Puskesmas Tanjung Morawa Kabupaten Deli Serdang. Universitas Sumatera Utara. (Tesis). 2011. Dari URL:http//www.ejournal.usu.ac.id. Diakses pada tanggal 28 Desember 2015.

Tim PTRM RSUD Gunung Jati Kota Cirebon. Laporan Tahunan Program Terapi Rumatan Methadon. Klinik PTRM RSUD Gunung Jati. Cirebon. 2014 
Faktor-faktor yang Mempengaruhi........ (Dessy A, Bagoes W, Kusyogo C)

Wawan.A. \& Dewi. Teori dan Pengukuran Pengetahuan, Sikap,

Dan Perilaku Manusia.. Nuha

Medika. Yogyakarta. 2011

Winarno.H. Faktor-Faktor Yang

Berhubungan Dengan Penggunaan
Jarum Suntik Bergantian Diantara Pengguna Napza Suntik Di Kota Semarang. UNDIP. Semarang. 2008 